Mette Guldberg, mag.art. i europæisk etnologi, Københavns Universitet 1989, ph.d. i historie, Århus Universitet 1998. Siden 1994 museumsinspektør ved Fiskeri- og Søfartsmuseet i Esbjerg, nu afdelingsleder for forskning og samlinger samme sted, samt seniorforsker ved Center for Maritime og Regionale studier, Fiskeri- og Søfartsmuseet/ Syddansk Universitet. Har udgivet en række publikationer om handel og søfart i den danske del af Vadehavet, herunder kontakten med Holland.

\title{
KØBMANDEN, SKIPPERNE OG HOLLANDSFARTEN Varer fra Holland til Jylland i 1700-tallet
}

Holland var i 1600- og 1700-tallet et nordeuropæisk centrum for handelen med varer fra de oversøiske kolonier, og mange jyske købmænd fik varer fra direkte fra Holland via havnene på den sydvestjyske kyst. Toldregnskaberne fra 1700-tallet er en glimrende kilde til visse aspekter af denne handel, mens andre spørgsmål lades åbne. Her kan man i stedet hente hjælp i de sjældne personlige beretninger, der findes fra tiden. En af dem er den østjyske købmand Rasmus Toxens optegnelser, som i denne artikel tages som udgangspunkt for en skildring af kontakten mellem den jyske provins og et af verdenshandelens centre.

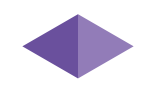

$I^{2}$ august 1737 tog Vejle-købmanden Rasmus Toxen (1716-1786) fra Hjerting om bord på en lokal smakke. Efter tre ugers sejlads ankom han til Amsterdam, hvor han solgte sine medbragte varer og købte nye, inden han tog tilbage med det samme skib. Efter endnu tre ugers sejlads ankom han til Hjerting, hvorfra han tog over land tilbage til Vejle. ${ }^{1}$

1 Berend 1906-08. Tak til dr. phil. Annette Hoff og mag. scient. Max Pedersen for konstruktive kommentarer til tidligere udkast til denne artikel. 


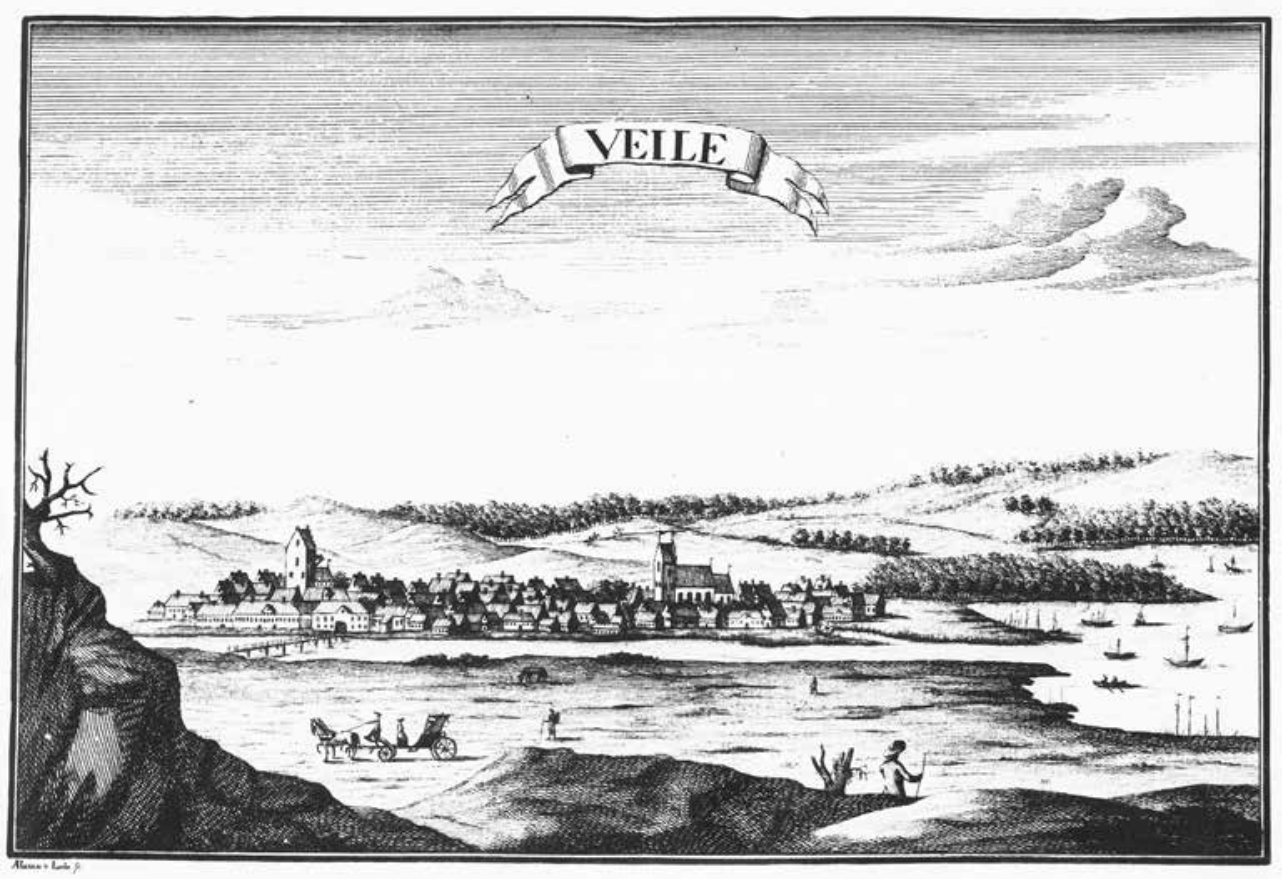

Rasmus Toxen (1716-1786) var født i den "liden og ringe by" Vejle. Her begyndte han i 1730'erne sin handelsvirksomhed, bl.a. med import fra Holland. Ved folketællingen 1769 havde Vejle 957 indbyggere. Pontoppidan: Den Danske Atlas V, 2, 1769.

Rasmus Toxen var kun en blandt mange jyske købmænd, der importerede varer fra Holland i 1600- og 1700-tallet. I denne periode var Holland centrum for handel med varer fra hele verden, og det Forenede Ostindiske Kompagni - VOC - var verdens største handels- og søfartskompagni med tusindvis af ansatte, omkring 30 holdepunkter i Asien og en flåde på mere end hundrede skibe. ${ }^{2}$ Fra Asien hjembragte skibene krydderier, silke, bomuld, kaffe, te, farvestoffer og meget mere, og i kølvandet på denne handel blomstrede håndværk og handel i Holland, ikke mindst i hovedbyen Amsterdam, som blev et arbejdsmarked, der tiltrak folk fra alle verdenshjørner.

Mange af de varer, der kom fra Holland til Danmark, gik over København, men enkelte provinshavne, herunder flere på den jyske vestkyst, havde selv direkte kontakt til Holland. ${ }^{3}$ Ikke mindst Vardes ladeplads, Hjerting, spillede i 1700-tallet en stor rolle i denne trafik, og mange varer kom til Jylland via Hjerting. Holland og Amsterdam spillede således en stor rolle set fra Jylland, mens Jylland - efter en voldsom nedgang i den tidligere så betydningsfulde studeeksport fra Danmark til Holland - i 1700-tallet set fra Amsterdams side var et forholdsvis uinteressant

Jacobs 1991 s. 95.

3 Se Monrad Møller 1981, s. 109f; Om trafikken på Ringkøbing se Mortensen 1991 og på Ribe, se Guldberg 1998. 


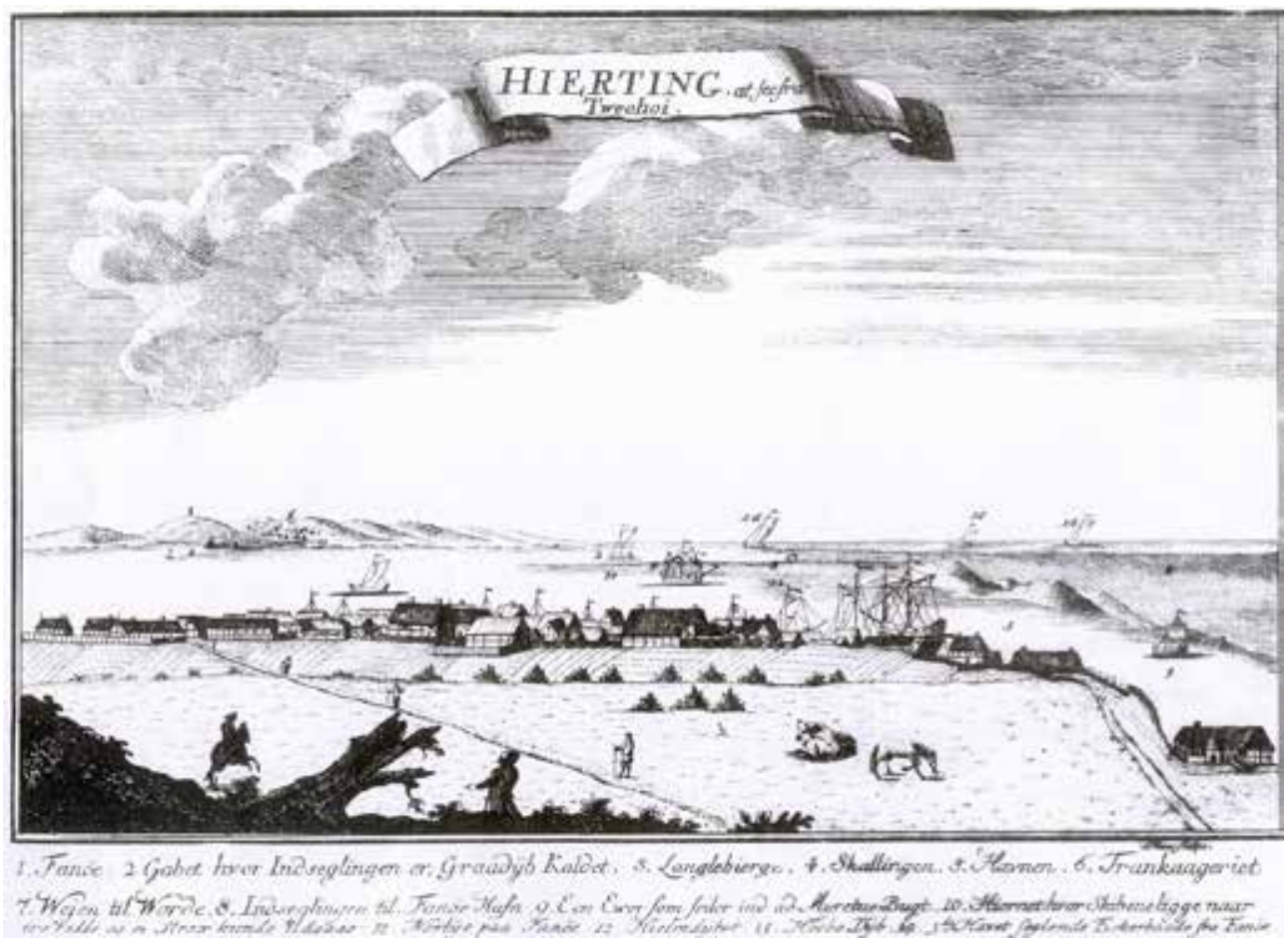

Vardes ladeplads Hjerting ved Grådyb var i 1700-tallet den største havn i den nordlige del af Vadehavet, og den fungerede som importhavn for varer fra Holland til store dele af Jylland. Som det var tilfældet flere andre steder langs den tidevandspåvirkede vadehavskyst, var der ikke noget egentligt havneanlæg. De fladbundede skibe sejlede tæt ind mod kysten ved højvande. Når de ved lavvande kom til at ligge på den tørlagte vade, kunne vognene køre helt ud til skibene for at laste og losse. Pontoppidan: Den Danske Atlas V, 2, 1769.

nærområde, der kunne levere grove bondevarer og billig arbejdskraft, men som ikke spillede nogen særlig rolle i den store økonomi.

Tidligere studier har vist, hvordan trafikken ved Hjerting udfoldede sig gennem 1700-tallet, hvor de bevarede toldregnskaber giver mulighed for detaljerede indblik i varetransporten og de skippere, der stod for den. Et af de slående træk er den mangfoldighed af varer fra bl.a. Holland, der ad denne vej blev indført til købmænd i byer over store dele af Jylland. ${ }^{4}$ Sværere er det imidlertid at få oplysninger om denne handel set fra købstæderne. Her findes der ofte kun spredte bemærkninger om betydningen af handelen på Holland og Hjertings rolle heri. Netop derfor er Rasmus Toxens beretning så værdifuld, idet den bidrager med sjældne beskrivelser af hændelsesforløb og handelsforhold set fra købmandens side. I denne artikel bruges Rasmus Toxens levnedsbeskrivelse til at nuancere og uddybe af de oplysninger, der kan udledes af toldregnskaberne. Gennem den personlige synsvinkel, som hans beskrivelse tilvejebringer, får vi værdifulde indsigter i ikke alene købmanden og hans virksomhed i de to købstæder, han virkede

4 Guldberg 2013. 
i, men også i, hvordan handelen på Holland rent konkret foregik, hvilke varer der blev hentet, hvilke havne og skibe der benyttedes, og hvordan personlige netværk indgik som et redskab i handelen.

Da temaet er handelen på Holland, er der ikke i denne sammenhæng gjort forsøg på at kortlægge Toxens samlede virksomhed. Hovedformålet er gennem inddragelse af en personlig synsvinkel at øge kendskabet til omstændighederne ved tilførslen af varer fra Holland til de jyske købstæder samt til, hvilken rolle købmanden spillede i disse relationer.

\section{Kontakten Danmark-Holland i dansk og udenlandsk forskning}

Trods Hollands store betydning og den livlige kontakt i 1600- og 1700-tallet er den hollandske indflydelse i Danmark ikke særligt velbelyst. Da et tobindsværk i 1945 satte fokus på kontakten Holland-Danmark, udtrykte redaktørerne i forordet ønske om, at emnet ville blive taget op og uddybet af andre forskere, ${ }^{5}$ men det er kun sket i relativt lille omfang. Når det er sket, har det primært drejet sig om den kontakt, der var knyttet til centraladministrationen og den danske konges interesser, først og fremmest den økonomiske meget betydningsfulde Sundtold, hvor andelen af nederlandske skibspassager gennem Øresund i perioder var helt oppe på 80 procent af alle passager. ${ }^{6}$

Når det derimod gælder kontakten fra den sydvestjyske kyst til Holland, var der tale om en kontakt, som foregik mellem almindelige mennesker, og som ikke nødvendigvis havde myndighedernes bevågenhed og accept. Emnet findes sporadisk behandlet i sammenhæng med søfarten fra området i bred almindelighed, med Arne Sundbos og H.K. Kristensens artikler fra henholdsvis 1919-22 og 1974-77 som to af de mere grundige lokalhistoriske arbejder. ${ }^{7}$ Under overskriften "Vestjylland og Verden" tog en gruppe kulturhistorikere med tilknytning til de sydvest- og vestjyske museer i begyndelsen af 1990'erne initiativ til et netværk, der arbejdede med Vestjyllands kontakt med omverdenen, og her var kontakten til Holland blandt de emner, der blev taget op. ${ }^{8}$

I Norge har interessen for kontakten med Holland været større end i Danmark, ikke mindst på grund af Norges store eksport af træ til Holland, der bevirkede, at der tidligere var områder på Sørlandet og Vestlandet, hvor ”hollændertiden” var

5 Fabricius et al. 1945.

6 Gøbel 2003, s. 20.Sundtoldens arkiver er en righoldig kilde til ikke mindst den hollandske søfart på Østersøen, og de har påkaldt sig mange forskeres interesse, fra den storstilede publicering af regnskaberne ved Nina Bang og Knud Korst i begyndelsen af 1900-tallet til nutidens digitaliseringsprojekt Sound Toll Registers Online ved Groningen Universitet.

7 Sundbo 1915-18 og 1919-22; Kristensen 1974, 1976 og 1977.

8 Guldberg et al. 1993; Damgaard et al.1998. 


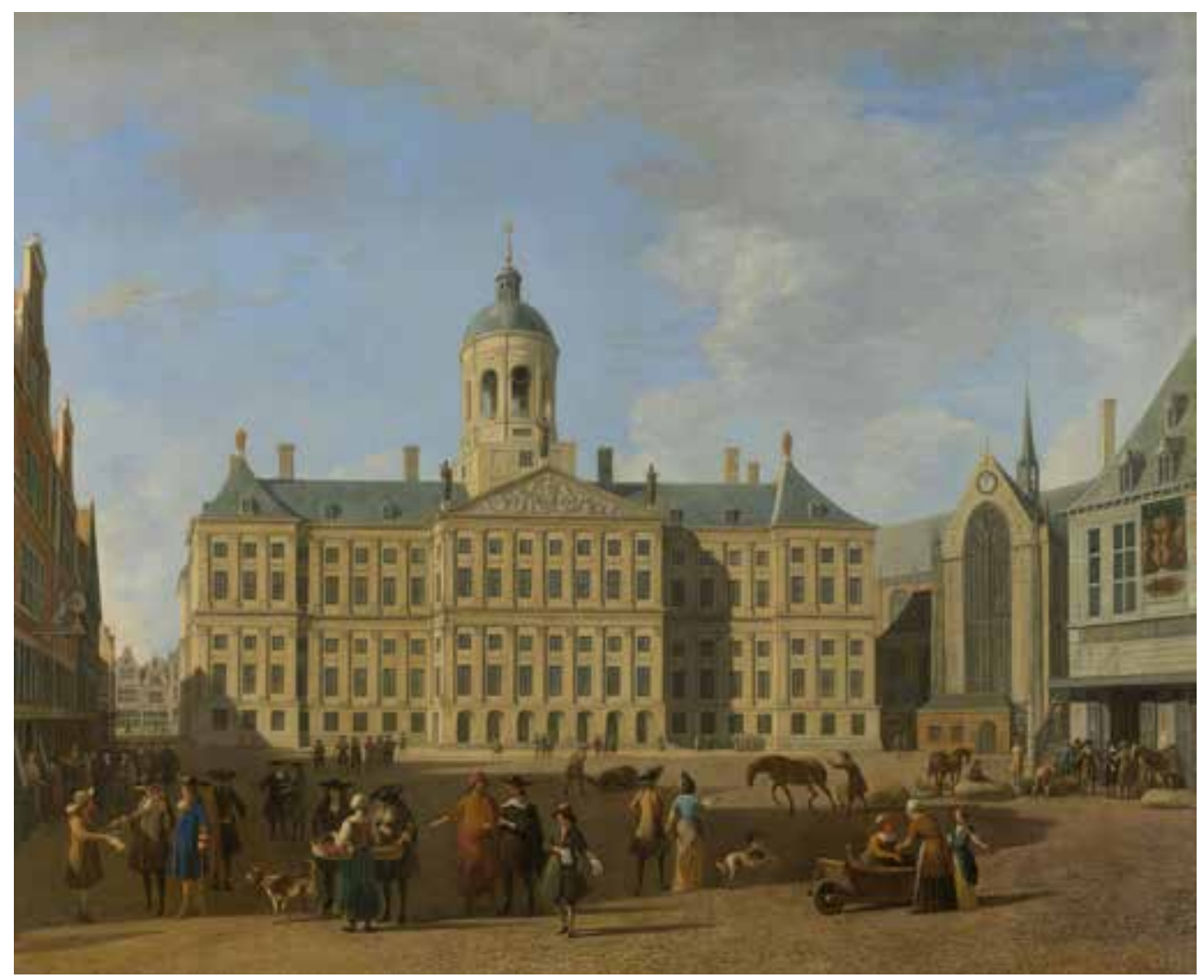

En af de bygninger, Rasmus Toxen utvivlsomt så i Amsterdam, var det imponerende rådhus på Dam opført 1648. Ved Toxens første besøg i byen i 1737 havde Amsterdam omkring $\mathbf{2 4 0 . 0 0 0}$ indbyggere. Rådhuset fungerer i dag som kongeslot. Gerrit Adriaenz Berckheyde: "Het Stadhuis op de Dam te Amsterdam" 1693. Rijksmuseum, Amsterdam.

et begreb på linje med ”i gamle dage”. ${ }^{9}$ Særligt har den norske historiker Sølvi Sogner arbejdet med migrationen fra Norge til Holland i bøgerne Ung i Europa og ”Og skuta lå i Amsterdam...". ${ }^{10}$ Danske pendanter til Sogners arbejde vedrørende udvandring til Holland er blevet udført af Esben Graugaard, når det gælder Holstebro, og af Max Pedersen med hensyn til vadehavskysten. ${ }^{11}$

Fra hollandsk side har man naturligvis beskæftiget sig med Hollands relationer til omverdenen i landets gyldne periode, og herunder også forholdet til nærområderne, dog sjældent specifikt med henblik på Danmark. Interessant i denne sammenhæng er antologien From Dunkirk to Danzig. Shipping and Trade in the North Sea and the Baltic fra 1988, der bringer en række artikler der kan medvirke til at belyse kontakten til Danmark. ${ }^{12}$ Det mest betydningsfulde hollandske ar-

9 Sogner 2012, s. 8.

10 Sogner 1994; Sogner 2012.

11 Graugaard 1996; Pedersen 2013; Pedersen og Thuijs 2014. Amsterdam som arbejdsmarked for søfolk er behandlet i Christensen 2014.

12 Heeres et al. 1988. 
bejde, når det specifikt gælder handelskontakten mellem Danmark og Holland, er imidlertid historikeren Wilma Gijbers doktorafhandling fra 1999 Kapitale Ossen. De internationale handel in Slachtvee in Noordwest-Europa (1300-1750) om den danske eksport af stude til bl.a. Holland. Afhandlingen er et enkeltstående udtryk for interesse fra hollandsk side i forbindelsen til Danmark. ${ }^{13}$ Siden har forskningsprojektet Close Encounters with the Dutch sat fokus på Nordsøen som en region, der lå nær centret for opkomsten af en moderne økonomi 15501750. Projektets formål var at analysere, hvordan Nordsø-regionen håndterede de udfordringer, nærheden til den første globaliserede økonomi med centrum i Amsterdam gav. Projektet, som var forankret på International Institute of Social History i Amsterdam, resulterede i tre ph.d.-afhandlinger om henholdsvis økonomisk integration omkring Nordsøen, den nederlandske indflydelse på migrationen i Nordsø-området og om det hollandske sildefiskeri. ${ }^{14}$

De senere år har dog vist en fornyet interesse i kontakten Danmark-Holland afspejlet i flere afhandlinger om emnet fra danske universiteter. Således er resultater fra tre specialer om den hollandske indflydelse på den danske maritime verden blevet publiceret inden for de senere år. ${ }^{15}$ Det mest betydningsfulde af disse senere arbejder er dog Phillip Kelsalls ph.d.-afhandling fra 2007, Crisis and Change. The Development of Dutch-Danish Maritime Trade 1639-1755. Kelsall giver med eksempler i en række danske byer en omfattende fremstilling af handelen mellem de to lande, som den udviklede sig i en periode på 116 år, med hovedvægt på søfarten og dens varer. Afhandlingen er desværre upubliceret. ${ }^{16}$

I 2012 påbegyndte Fiskeri- og Søfartsmuseet sammen med Museum Sønderjylland på en bevilling fra Kulturstyrelsen et projekt med det formål at undersøge, hvad de danske Vadehavs-egnes forbindelser til Holland i 1600-1700-tallet betød for samtiden. I første omgang beskæftigede projektet sig med migration og vareudveksling, mens den fremtidige indsats vil fokusere på Amsterdam som en af hovedbyerne i datidens globaliseringsproces og dens relationer til Danmark anskuet som et udkantsområde i dens nærhed. Hvordan skete udvekslingen af kapital, varer, ideer, information og mennesker, og hvilken virkning havde den på den brede befolkning? De hidtidige resultater af projektet er præsenteret i en række artikler, ligesom denne artikel skal ses som et led i dette projekt. ${ }^{17}$

\footnotetext{
Gijsbers 1999.

Lottum 2007; Bochove 2008; Poulsen 2008.

Thaarup 2012; Rohden 2012; Christensen 2014.

Kelsall 2007.

17 Projektdeltagere i første del af projektet var museumsinspektør Elsemarie Dam-Jensen, mag. scient. Max Pedersen og museumsinspektør Mette Guldberg. De hidtil publicerede artikler er Pedersen 2013; Pedersen og Thuijs 2014; Guldberg 2013; Guldberg 2014. Tak til Kulturstyrelsen for støtte til projektet. Også tak til Kulturministeriets Forskningsudvalg projektmodningsmidler 2013-14 til den kommende indsat. Her består projektgruppen, foruden ovennævnte, også af professor Martin Rheinheimer, Syddansk Universitet (projektleder) og cand. mag. Asger Nørlund.
} 


\section{Toldregnskaber og optegnelser}

Gennem 1700-tallets toldregnskaber kan man få et detaljeret billede af skibstrafikken mellem Hjerting og Holland. For Varde toldsted med ladestedet Hjerting, er der bevaret syv toldbøger i deres helhed, nemlig 1731, 1733, 1761, 1763, 1767, 1769 og 1798. ${ }^{18}$ Toldbøgerne indeholder bl.a. optegnelser over de enkelte ekspeditioner af indkommende og udgående skibe med angivelse af ekspeditionens dato, skipperens navn og hjemsted, skibets drægtighed (størrelse), hvor det kom fra eller agtede sig hen, en specifikation af ladningen og hvem der ejede varerne samt de forskellige told- og afgiftsbeløb.

Toldbøgernes store svaghed som kilde er, at der givetvis er en hel del varer, der ikke er blevet underkastet toldbehandling. Det er så godt som umuligt at anslå omfanget af smugleriet, men at dømme efter utallige beretninger og klager har smugleriet ikke været ubetydeligt. ${ }^{19}$ Derfor er det hovedsagelig som en kilde til varernes art, toldbøgerne kan bruges. Når en varetype optræder i toldbogen, kan man med god ret gå ud fra, at den rent faktisk har forekommet på stedet. Derimod er mængdeangivelserne mindre troværdige, og toldregnskabers værdi som kvantitativ kilde må siges at være tvivlsom. ${ }^{20}$

Toldregnskaberne giver således giver gode oplysninger om skibene, skipperne og varerne, ligesom de fortæller om købmænd fra en lang række jyske byer som var modtagere og afsendere af varer. Derimod får man mindre at vide om, hvem der var om bord på skibene, hvad omstændighederne var omkring handelen med varerne og om købmændenes ageren. Hvordan var det at rejse til Holland? Hvad var skipperens rolle? Hvad skete der rent faktisk i Amsterdam?

Det er nogle af de spørgsmål, toldregnskaberne lader ubesvaret.

I den forbindelse er personlige optegnelser af uvurderlig betydning, og Rasmus Toxens optegnelser bidrager med mange interessante oplysninger, der kaster lys over denne side af samhandlen mellem Amsterdam og de jyske byer i 1700-tallet. Med sådanne såkaldte egodokumenter kan man få et enestående indblik i, hvordan en samtidig person oplevede de forhold, der kan aflæses ud af toldregnskaberne, og dermed tilføjes værdifulde nuancer til det samlede billede. ${ }^{21}$

Købmanden Rasmus Toxen begyndte sin handelsvirksomhed i Vejle omkring 1737 og flyttede den til Horsens i 1740. Hans optegnelser, der omfatter tiden fra hans faders fødsel i 1679 til 1785, årets før Toxens død, findes udgivet i Samlinger til Jysk Historie og Topografi 1906-09 under redaktion af fhv. adjunkt C. Beh-

18 Varde Toldbøger, 1731, 1733, 1761, 1763, 1767, 1769 og 1798, Rigsarkivet. For nærmere præsentation af materialet se Møller 1975.

19 Se f.eks. Becker-Christensen 1988 s. $388 \mathrm{ff}$; Kromann 1933, s. 263 ff.

20 Møller 1975, s. 99; Mortensen 1989.

21 Begrebet "ego-dokument" blev lanceret i 1958 af Jacques Presser og betegner historisk materiale som er skrevet i første person ental og som udtrykker personlige tanker og følelser, som dagbøger, breve, autobiografier og rejsebreve. Jf. Sogner 2012, s. 171. 
rend. ${ }^{22}$ Skriftet var ved udgivelsen i familiens eje, og redaktøren har ikke knyttet kommentarer til udgivelsen. Det fremgår således ikke, om der er tale om optegnelser nedskrevet gennem hele livet eller de er skrevet i retrospekt. Manuskriptet er tilsyneladende gengivet med den oprindelige retskrivning, og udeladelser er angivet med en kort redegørelse for, hvad der er udeladt - deriblandt en i denne sammenhæng ærgerlig udeladelse af en nærmere beskrivelse af en sejlads til Holland og indsejlingen til Amsterdam i 1751. Optegnelserne afsluttes med svigersønnens korte notits om Toxens død den 23. december 1786.

I denne artikel suppleres Rasmus Toxens beretning, hvor det er muligt, med samtidige beskrivelser af hans to hjembyer, Vejle og Horsens, som de bl.a. forekommer i stiftsrelationerne fra 1735 og andre indberetninger vedrørende købstæderne i 1700-tallet. ${ }^{23}$ Derimod er der ikke inddraget supplerende arkivmateriale til belysning af Toxens engagementer, idet det her er de mere subjektive aspekter i Toxens fremstilling, der er i fokus, frem for en udtømmende kortlægning af hans økonomiske aktiviteter.

\section{Toxen i Vejle i 1730'erne}

Rasmus Toxen blev født i Vejle i 1716. Hans far, der var præstesøn fra Løsning mellem Vejle og Horsens, havde stået i købmandslære i Holbæk og drev en krambod i Vejle. Faderen døde dog allerede i 1719, da Rasmus Toxen kun var tre år gammel, og drengen voksede op hos sin mor, som ifølge J. K. Jensen drev kramboden videre, med tiden med hjælp af Rasmus. ${ }^{24}$ Som 17-årig blev han i 1733 sat i guldsmedelære hos noget af sin fars familie på Fyn. Her blev han imidlertid uenig med læremesteren, afbrød opholdet og tog tilbage til Vejle. Omtrent på denne tid beskrives Vejle sådan her i stiftsrelationerne fra 1735:

”Denne liden og ringe Bys Handel og Handtering, Næring og Brug bestaar ej udi andet end en liden Handling for Bonden, Landmanden og Byens Indvaanere, som drives af nogle faa af Byens Borgere og Indvaanere". ${ }^{25}$

22 Behrend 1906-08. Det vides ikke, hvor originalmanuskriptet findes. Svend Nørregaard og Bodil Møller Knudsen fra Byarkivet i Horsens har forgæves eftersøgt manuskriptet i begyndelsen af 1990'erne. Venligst oplyst af Bodil Møller Knudsen. Oplysninger om manuskriptets skæbne vil blive modtaget med taknemmelighed.

23 Stiftsrelationerne for Vejle er publiceret i Christensen 1921 og for Horsens i Bay 1982. Der er forskellige principper for gengivelse af relationernes tekst. Her har jeg overalt valgt at bibeholde den form, hvori de findes i den udgivelse, der citeres fra.

24 Jensen 1944, s. 248.

25 Christensen 1921, s. 176. 
Byen havde ingen skibe, kun havde en borger halvpart i en galeot på 13 læster, ${ }^{26}$ som var hjemmehørende i Flensborg. "Kiøbmænd og Kræmmerlaug er her i Byen ganske og aldeles ingen af; enhver handler, som han bedst ved og kan."27 Vejles handlende var da heller ikke blandt storforbrugerne af Hjerting som transithavn for varer til og fra Holland, men vi finder dog i Vardes toldbøger to handlende fra Vejle, som fik varer ad denne vej. De optrådte begge i 1731, hvor de fik varer med samme skib, nemlig Knud Risbøls smakke på 13 læster. ${ }^{28}$

Den ene Vejle-borger var en Søren Rasmussen, som formodentlig var identisk med byskriveren Søren Rasmussen Egtved, om hvem det i 1735 hed, at han på grund af den ringe løn var nødsaget til at drive handel ved siden af sit embede for at kunne forsørge sin kone og sine små børn. ${ }^{29}$ Søren Rasmussen havde i 1735 været i byen i fire år, så han var altså ganske nytilflyttet, da han i 1731 fik varer fra Holland over Hjerting. Inden han kom til Vejle havde han i 12 år beklædt en stilling som fuldmægtig hos stiftamtmanden i Ribe. Muligvis havde han fra den tid opbygget et kendskab til Vadehavskysten og dens søfart, der gjorde det let for ham ad denne vej at skaffe varer til sin nyetablerede handelsvirksomhed. I hvert fald fik han en sending varer fra Holland over Hjerting med Knud Risbøls smakke, der ankom 17. maj 1731. Som varer i Søren Rasmussens kramhandel nævner stiftsrelationerne hør, hamp, humle, tjære, salt, tran, fisk og "lidet specerier". Af listen over de varer, han importerede fra Holland fremgår det, at det primært var varer i sidstnævnte kategori, han hentede der, altså krydderier og andre varer, der kunne bidrage til at sætte kolorit på den daglige kost.

Den samlede sending bestod af forskellige varer med en samlet vægt på godt 313 pund, hvortil kom 500 stk. valnødder, et ris papir og en halv tønde hirsegryn samt "1 Td. gamle udbrennte Tobachspiber af Værdie 2 Rdl." 30 Denne sidste vare var en genbrugsvare fra det rige Holland: brugte kridtpiber som, når de blev brændt rene, godt kunne bruges igen. Mens nye kridtpiber blev regnet i dusin, blev gamle udbrændte tobakspiber regnet i tønder.

”Der findes næppe 10 dusin hele piber i en tønde, men stumper og stykker. Købmændene bruger dem til at give bonden til en tilgift, for derved at trække hannem til sig," forklarede toldvæsenet, da revisionen undrede sig over, at de ikke blev fortoldet som andre piber. ${ }^{31}$

\footnotetext{
26 En galeot var en almindelig skibstype i 1700-tallet. En læst, som var datidens enhed for skibsmåling, svarer i udgangspunktet til ca. to registertons, med der var store forskelle i brugen af målet. Møller 1981, s 59 og 46.

27 Christensen 1921, s.182 og 184.

28 Varde Toldbog 1731 indkommende nr. 20.

29 Christensen 1921, s. 189 f.

30 Et pund svarede ved denne tid til 496 gram. 1 ris papir betegner en mængde papir svarende til 20 bøger. En korntønde indeholdt 139,1 liter. Thestrup 1991.

31 Her citeret efter Kristensen 1976 s. 98.
} 


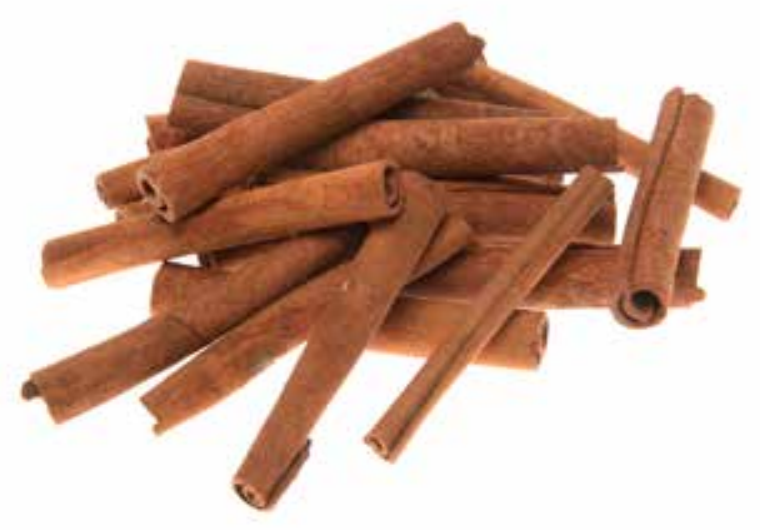

Nogle af de krydderier, der typisk blev indført fra Holland til de jyske købstæder: kanel, muskatnød og nelliker. Foto: Brian Kristensen.

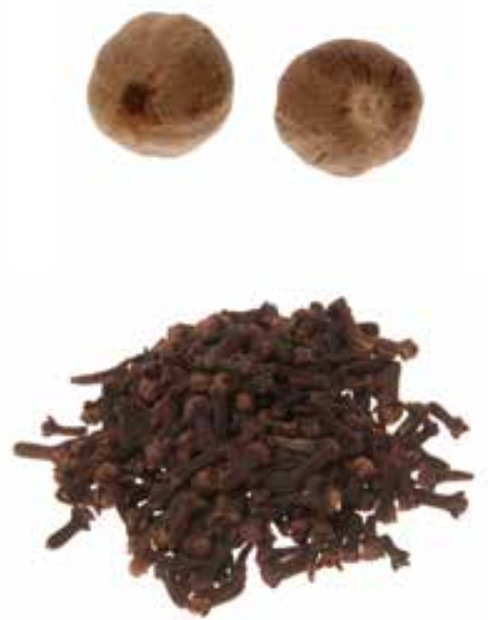

De egentlige krydderier udgjorde kun to et kvart pund ud af sendingen på godt 313 pund. Det var de klassiske krydderier, som hollænderne bragte med sig hjem fra Ostindien: kanel, kardemomme, nelliker, muskatnødder og muskatblomme - et halvt pund af hvert af de fire første og et kvart pund af det sidste. Sukkervarer var der 14 pund af, mens tørrede frugter udgjorde 100 pund eller knap en tredjedel af vægten i den del af sendingen, der måltes i pund. Her var der tale om 25 pund af henholdsvis svesker og figner, 20 pund rosiner samt 10 pund af henholdsvis ingefær, korender og mandler. Forskellige grynvarer - ejergryn, ${ }^{32}$ perlegryn, risengryn, hirsegryn - udgjorde 80 pund, og det samme gjorde materialvarerne: farvestofferne krap, indigo og himmelblå samt stivelse, bleghvidt og harpiks. Endelig var der i sendingen 25 pund krudt og 12 pund hagl.

Den anden handlende fra Vejle, der fik varer med skibet, var Mogens Risum, om hvem det i en fortegnelse over Vardes borger fra 1735 hed, at han var medlem af skrædderlauget, og at han, så vidt man vidste, sad lidt bedre i det end sine fagfæller. ${ }^{33}$ I 1731 sendte Mogens Risum en sending varer bestående af pennefjer for fire rigsdaler og en deger - dvs. 10 stk. - kalveskind med Knud Risbøls smakke, der som det første skib det år forlod Hjerting med kurs mod Holland den 2. april. Skibets hovedlast var 200 tønder rug, som blev eksporteret af forpagter Termann Madsen på Krogsgaard, og derudover havde det uld, voks, talg, pennefjer, kalveskind, børster og vadmel med for et par borgere i Holstebro. Desuden medbragte skibet "Eendeel Søefarende Folk, som agter Hyre at søge". ${ }^{34}$ Sådanne søfolk var et fast tilbagevendende indslag på forårets skibe til Holland, hvor de

32 Ejergryn er fine boghvedegryn iflg. Lange 1793, s. 217.

33 Christensen 1921, s.196.

34 Varde Toldbog 1731, udgående nr. 15. 
vestjyske søfolk efter vinteren hjemme skulle ned at søge hyre på de store skibe fra Amsterdam - hvalfangere, ostindiefarere eller hvad der måtte byde sig.

Da skibet returnerede fra Holland den 17. maj 1731, medbragte det "Gamle Luus Krams Klæder og Klude af Værdie 30 Rdl." til Mogens Risum. ${ }^{35}$ Luskramsklæder og -klude var endnu en genbrugsvare fra Holland, og sådant genbrugstøj var en stor artikel i 1731, hvor tyve forskellige importører i Varde, Holstebro, Nykøbing Mors, Lemvig, Horsens og Ringkøbing fik luskram over Hjerting. I toldbogen to år efter, i 1733, fandtes det ikke, sikkert som en direkte følge af, at det i den nye toldrulle fra 1732 hed, at klæder, "gamle og brugte maa ikke indføres til at selge". ${ }^{36}$ Toldbogen melder intet om, hvorvidt Mogens Risum selv var med i Holland, men det er ikke usandsynligt, eftersom han både førte varer ud af landet og med ind igen. Desuden var genbrugstøj formentlig en varetype af en sådan karakter, at forhandleren gerne selv ville med for udsøge sig de salgbare stykker. ${ }^{37}$

De to importørers varer giver et godt indtryk af handelen mellem Holland og de jyske købstæder. Til Holland eksporteredes korn, groft forarbejdede varer og arbejdskraft, og fra Holland importeredes kolonialvarer og genbrugsvarer.

\section{Skipper Risbøl i Hjerting}

Det skib, de to handlende begge benyttede, var skipper Knud Risbøls kun tre år gamle smakke på 13 læster. Det var ligesom de øvrige af toldstedets nyeste og største handelsskibe bygget i Altona. Toldstedets ældre skibe - det ældste var 27 år gammel - var hentet i Holland og Frisland, mens småbådene var bygget lokalt. 30 år senere var Altona det altdominerende byggested for skibene ved toldstedet. $^{38}$

Toldstedets hovedhavn var Hjerting, købstaden Vardes ladeplads. Købstædernes privilegier omfattede ikke alene handel og håndværk, men også søfart. Det betød, at man som udgangspunkt skulle være borger i en købstad for at kunne drive søfart, og at de transporterede varer skulle fortoldes ved købstadens toldsted. Imidlertid var adgangsforholdene med skib op ad Varde $\AA$ til Varde så dårlige, at toldstedet i 1692 flyttede fra Varde til byens største ladested, Hjerting, som lå ved vadehavskysten. I 1700-tallet havde Hjerting overtaget Ribes stilling som den største havn i det nordlige Vadehav. Den før så driftige havneby, Ribe, havde i 1731 kun ét hjemmehørende skib tilbage. ${ }^{39}$ Hjerting rådede derimod i 1731 over

35 Varde Toldbog 1731 indkommende nr. 20.

36 Becker-Christensen 1988, s. 329.

37 I Fabricius et al. 1945 bd. I s. 221 fortælles der, desværre uden nøjagtig kildeangivelse, om to kvindelige lusekræmmere fra Lemvig, der selv tog med skib til Holland for at søge varerne ud.

38 Diverse skibslister fra toldregnskaberne. Se også Guldberg 2014.

39 Om trafikken på Ribe, se: Guldberg 1998. 
19 skibe, hvoraf de to største tog på sælfangst i Nordhavet, mens de øvrige primært sejlede på Elben, Holland og Norge.

Skipper Knud Risbøl (ca. 1694-1737) tilhørte en familie, der havde været en markant del af søfartssamfundet i Hjerting siden slutningen af 1600-tallet, og Risbølnavnet optræder i flere sammenhænge, når det handler om kontakten til Holland. I Hjerting var der i 1731 og 1733 henholdsvis syv og fem skibe, der varetog trafikken til Holland, heriblandt to Risbøl'er, Knud og Peter. ${ }^{40}$

Knud Risbøl var hvert af de to år flere gange i Holland, og derudover sejlede han til Norge, Elben og Glückstad. Hans laster fra Holland var overordentlig sammensatte, og hans kundekreds kom fra store dele af Jylland. Således havde han ved ankomsten den 17. maj 1731 - den last der indeholdt Søren Rasmussens specier og Mogens Risums luskram - varer med for 16 andre personer, der kom fra Holstebro, Lemvig, Ringkøbing, Nykøbing, Varde og Guldager, foruden 4000 mursten til sig selv. I alt havde Knud Risbøl 34 personer fra 12 forskellige lokaliteter som kunder på sine hollandssejladser de to år, vi kan følge ham i Toldbøgerne, 1731 og 1733. Importkunderne var langt de fleste, mens kun få sendte varer med ham til Holland. Eksportvarerne var - ud over små mængder af uld, voks, talg, pennefjer, kalveskind, børster og vadmel - primært korn for et par herregårde. I et enkelt tilfælde fyldte han den overskydende plads på skibet op med sorte potter for egen regning. De sorte potter, bedre kendt som jydepotter, blev produceret i landsognene på Vardeegnen og eksporteret i stort tal fra Hjerting i 1600- og 1700-tallet. ${ }^{41}$

\section{Toxens rejser til Holland i 1730'erne}

I 1736 gik den 20-årige Rasmus Toxen med en afbrudt læreplads bag sig rundt i den "liden og ringe by" Vejle og fik udlængsel: Han fik "lyst til at reise og see (sig) om $i$ Werden”. ${ }^{42}$ Han besøgte i den følgende tid København, Eckernförde, Kiel og Hamburg, hvor han tilbragte vinteren hos noget familie, et barn af en af hans søskende. Han blev i Hamburg indtil pinse 1737, hvorfra han ville have fortsat til Amsterdam, hvis ikke han var blevet syg og måtte opgive rejsen. I stedet købte han bomuld, lærred og lignende for de penge, han skulle have brugt på turen, og tog hjem til Vejle med en skipper fra Hjerting.

Allerede i august 1737 var han dog klar igen og lejede en vogn til Hjerting, hvor han og hans varer kom om bord på skipper Knud Risbøls enkes fartøj, en smakke, der skulle til Amsterdam. ${ }^{43}$ Det var med stor sandsynlighed den samme

40 Om Risbøl'erne i Hjerting, se: Guldberg 1997.

41 Guldberg 1999.

42 Behrend 1906-08, s 578.

43 Behrend 1906-08, s. 579. 
smakke, som de to Vejle-folk, Mogens Risum og Søren Rasmussen, seks år tidligere havde fået varer med, og som enken nu stod for, her få måneder efter Knud Risbøl var død 13. maj 1737, 43 år gammel. ${ }^{44}$ Turen markerede begyndelsen på Toxens rejser til Amsterdam, der blev hans foretrukne mål, når han i årene fremover skulle hente varer til sine handelsaktiviteter. Måske var Rasmus Toxen lidt af en pioner, da han i 1737 indledte sin import fra Holland til Vejle, måske lod han sig blot inspirere af de erfaringer, byskriveren og skrædderen allerede havde med at finde den rette skipper i Hjerting og handle med Amsterdam.

Efter tre ugers sejlads ankom skibet med Toxen til Enkhuizen på Zuiderzeekysten, syv mil nord for Amsterdam. ${ }^{45}$ Toxen skriver ikke, hvordan de kom videre til Amsterdam, men da han senere omtaler, at skibet blev liggende i Amsterdam, er det nærliggende at antage, at de sejlede helt ind til byen. Amsterdam havde i 1730 omkring 240.000 indbyggere og må have udgjort en enorm kontrast til Vejle, som på det tidspunkt ikke engang havde tusind indbyggere. ${ }^{46}$ Byens gader var brolagte med fortov på hver side, og siden 1650 havde der været offentlig gadebelysning. I 1689 blev der således hver aften tændt 2400 lamper på byens gader. Fra sin rejse i 1670'erne beskrev Holger Jacobæus, biskopsøn fra Århus, hvordan Amsterdam var berømt for sine flotte gader og imponerende bygninger og hvordan købmænd fra hele verden - polakker, persere, jøder og andre, klædt på højest forskellig vis - mødtes på Børsen. ${ }^{47}$

Da det var første gang, Toxen var i Amsterdam, og han derfor ikke var kendt i byen, skaffede skipperen ham kontakt til en kommissionær, som hjalp ham med at sælge de skind- og lædervarer, han havde medbragt. Derefter foretog han en fire dage lang rejse til Haag gennem Haarlem og Leiden. Tilbage i Amsterdam brugte han den sidste del af de i alt fire uger, skibet lå i byen, til at kigge sig omkring og til at købe nye varer for de penge, han havde fået for sine egne varer. Her gik han først og fremmest efter det silketøj, som jøderne handlede med. Han havde tid nok til at se byen, skriver han, så det virker som om, han nåede, hvad han ville.

Efter de fire uger i Amsterdam vendte skibet hjemad, og efter endnu tre ugers sejlads ankom det til Hjerting, hvorfra Toxen tog over land tilbage til Vejle. Han må have haft gode erfaringer med rejsen, for straks året efter, i 1738, var han igen af sted to gange til Amsterdam foruden en gang til Hamburg, og i 1739 var han mindst to, måske tre, gange i Amsterdam.

Allerede på sin anden rejse, som han påbegyndte lige efter pinse 1738, var Toxen blevet mere dreven. Han behøvede nu kun en uge i Amsterdam til at "ekspedere sig”, og han tog med en anden skipper hjem end ham, han var kommet med. Efterårsrejsen 1738 forløb også planmæssigt, men forårsrejsen 1739 blev

44 Nyborg 1988-91, s. 2094.

45 Han regner formentlig i danske mil, hvor en mil er $7,538 \mathrm{~km}$.

46 Gawronski (ed.) 2012 s. 80; Feldbæk 1990, s. 79.

47 Sogner 2012, s. 39ff. 
dramatisk. Skibet kom i vanskeligheder ud for den frisiske vadehavsø Ameland og løb på grund. Tilsyneladende havde Toxen denne gang ikke varer med, men rede penge. I hvert fald fortæller han, at "min Kuffert med ald min Capital (nær) hafde gaaet overbord". Skibet blev dog reddet takket været nogle og halvtreds matroser, som var med om bord, fordi de skulle til Amsterdam og søge hyre. ${ }^{48}$ Mens Toxens første rejse fra Hjerting til Amsterdam i 1737 havde taget tre uger hver vej, gik denne stormfulde rejse langt hurtigere, idet skibet forlod Hjerting langfredag og var i Amsterdam anden påskedag, altså fire dage. Allerede 1. maj 1738 var Toxen tilbage i Vejle, fem uger efter, han havde påbegyndt rejsen fra Vejle.

Næste Amsterdam-rejse, som Toxen påbegyndte ved midsommer 1739, blev omstændelig og langvarig. Han indledte rejsen med at tage til marked i Horsens med sine varer, ${ }^{49}$ og derfra tog han til Hjerting for at komme med et skib til Amsterdam. Her var alle skibe imidlertid allerede sejlet, så i stedet kom han med et Fanø-fartøj, der skulle mod Hamburg. Efter 10-12 dages venten på Fanø og fire dages sejlads blev han sat af ved Neuhaus et lille stykke oppe ad Elben og kom med et andet fartøj ind til Hamburg. Her benyttede han lejligheden til at besøge sine venner, inden han kom med en hollænder til Amsterdam. Alene denne sidste del af turen fra Hamburg til Amsterdam tog tre uger. Tre gange forsøgte de at sejle ud på Vesterhavet, og tre gange måtte de tilbage igen på grund af storm og modvind. Da de endelig nåede Amsterdam, lå alle Hjerting-skipperne klar til at sejle hjem, så dem kunne han ikke nå at komme med, hvis han samtidig skulle have tid til at handle. I stedet måtte han tage med et skib fra Ringkøbing, en tjalk, der - som han malende beskriver - var læk, når de kom på søen og tæt, når de kom i havn. ${ }^{50}$ Skibet var tre uger om turen til Ringkøbing, og her måtte han blive endnu tre dage for at få sit gods fra fartøjet, før han endelig kunne begive sig hjem. ${ }^{51}$

\section{Fra Vejle til Horsens}

Måske var Toxens besøg på markedet i Horsens kort efter midsommer 1739 en slags rekognoscering med henblik på at finde ud af, om der var bedre etableringsmuligheder dér. I hvert fald flyttede han i 1740 de ca. $30 \mathrm{~km}$ fra Vejle til Horsens og flyttede dermed også til en by, der var mere end dobbelt så stor som Vejle. ${ }^{52}$ I

48 Behrendt 1906-08, s. 580.

49 Ifølge Pontoppidan blev der holdt marked i Horsens 27. juni og 8. oktober med kramvarer, heste og kvæg. Pontoppidan 1768, s. 138.

50 En tjalk var en skibstype karakteristisk for den syd-og sønderjyske vestkyst. Møller 1981, s. 62.

51 Om trafikken på Ringkøbing, se Mortensen 1991.

52 Der findes ikke nøjagtige tal for indbyggertallet i begyndelsen af 1700-tallet, men det antages, at befolkningstallet voksede med en tredjedel gennem 1700-tallet. Ved folketællingen 1769 havde Vejle 957 indbyggere, mens Horsens havde 2.738. Feldbæk 1990 s. 79. 


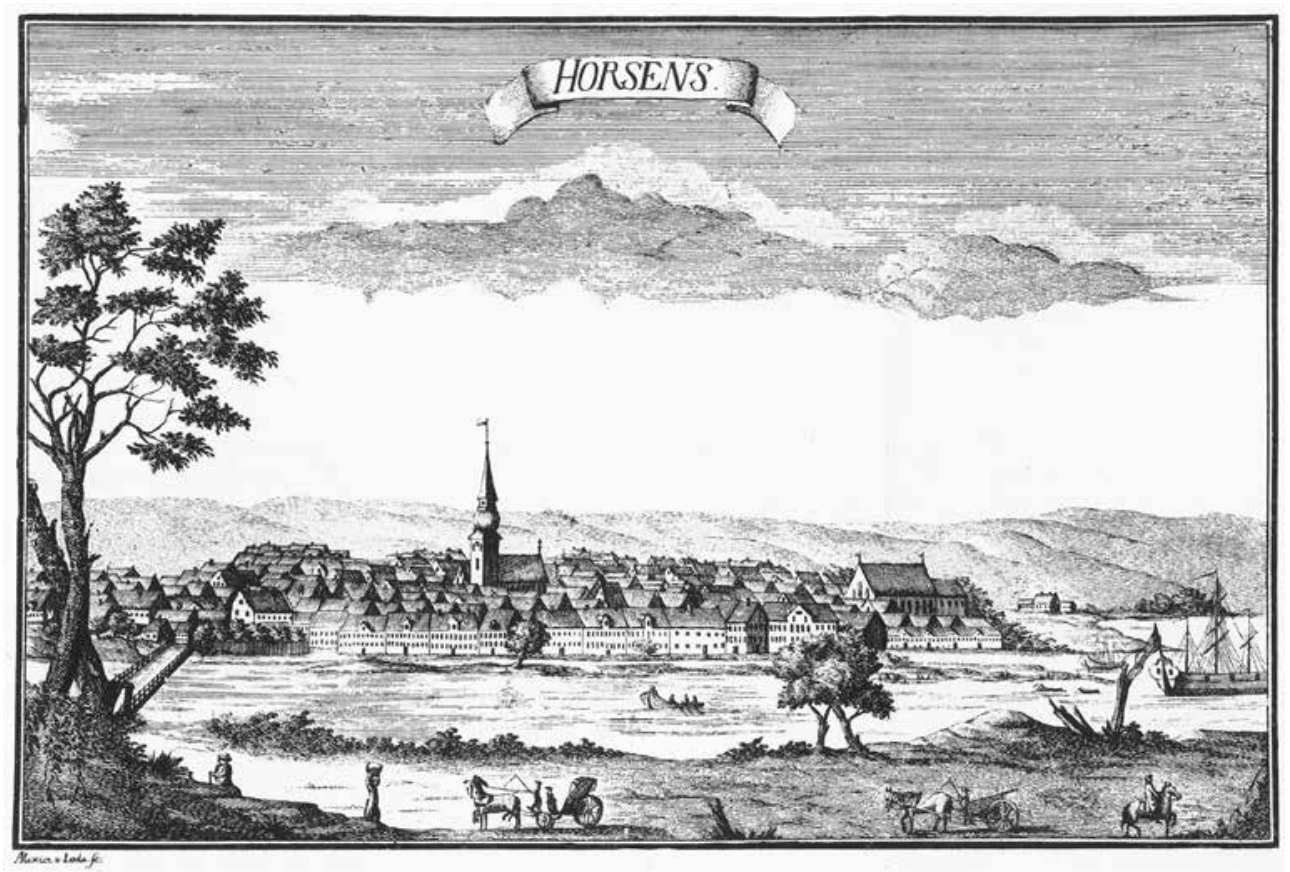

I 1740 flyttede Rasmus Toxen fra Vejle til den noget større købstad Horsens, hvor han gennem de følgende årtier opbyggede en større handelsvirksomhed. Ved folketællingen 1769 havde Horsens 2738 indbyggere. Pontoppidan: Den Danske Atlas IV, 2, 1768.

de følgende år opbyggede og udviklede Toxen gradvis sin virksomhed i Horsens fra krambod til købmandshandel og avlsbrug samt investeringer i ejendomme, produktionsapparat og skib.

Horsens havde i 1735 en flåde på 24 skibe, som stod for at indføre udenlandske varer til byen fra Flensborg, Lübeck og København. Men der var også handlende, der i begyndelsen af i 1730'erne hentede varer fra Holland over Hjerting: Ditlev Høyer fik både i 1731 og 1733 sukker og andre kolonialvarer fra Holland, Anne Jensdatter fik en sending luskramsklude i 1731, og Niels Møller fik i 1733 - med skipper Knud Risbøl fra Hjerting - en sending bestående af te, kaffe, sukker, anis og korender. ${ }^{53}$ Derudover foregik der tilsyneladende også en handel fra Holland, som gik uden om byen, idet stiftsrelationerne beretter, at

"en del på alle kanter 2 á 3 mil nær byen bosiddende rejser til Holland og derfra indfører vin, fransk brændevin, te, sukker og specerie, som de falholder og ved commissioner forsyner proprietærerne og præsterne ved hjemkomsten, hvilket forårsager handelens slette fremgang." ${ }^{54}$ 


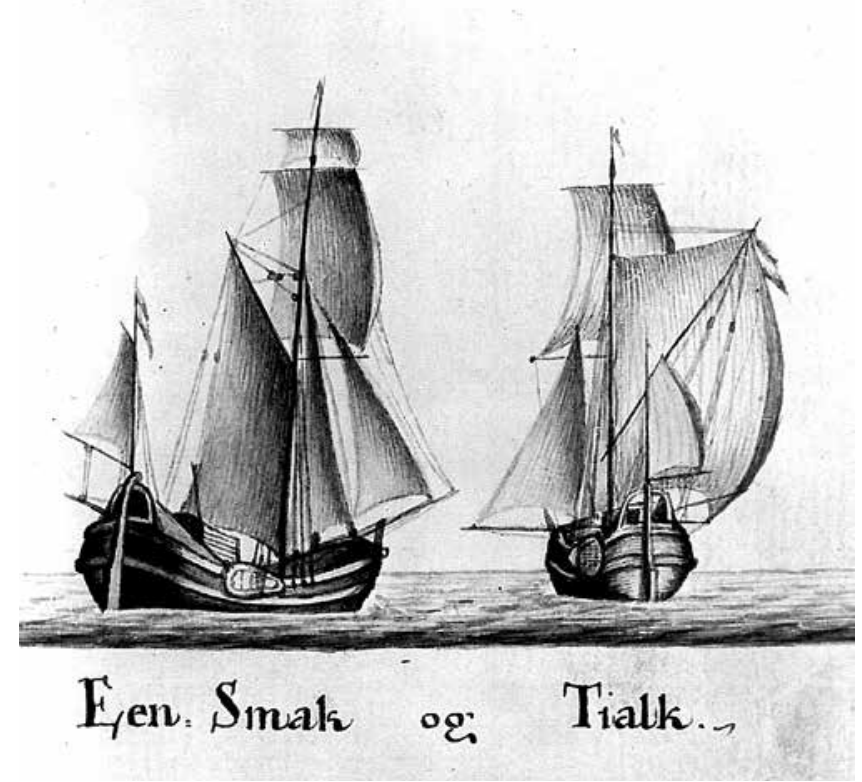

En smakke og en tjalk. To typer fartøjer, man kunne møde i Vadehavet, og som Toxen bragte varer hjem på fra Holland. Ved Hjerting var smakken den almindeligste skibstype. Brødrene Stibolt, 1760'erne. M/S Museet for Søfart.

Horsens havde tilsyneladende tidligere haft direkte skibsforbindelse til Holland. Således fortælles det i Pontoppidans Danske Atlas, at Horsens for 50 år siden - dvs. i de første tiår af 1700-tallet - havde skibe, der handlede på Holland, England og Norge, men at skibene nu i 1768 var langt mindre og sejlede på Norge, København, Østersøen og Flensborg. Atlasset opgiver antallet af skibe i byen til at være 17, syv mindre end stiftsrelationernes opgivelse i $1735 .^{55}$

Denne direkte hollandske forbindelse ses også af den handel, som Horsens-købmanden Hans Christensen og hans hustru Gedske Lichtenberg førte i 1690'erne. Ved Gedske Lichtenbergs død i barselsseng i 1697 får man gennem skiftet indsigt i deres handelsforbindelser, som ud over tre købmænd i Lübeck, fem i Hamburg også indeholdt to navne i Amsterdam: Bernhard Peltzer og Thomas Krysenbergs enke, til hvem der skyldtes henholdsvis 150 og 128 rigsdaler for varer. Skiftet fortæller ikke, hvilke varer det drejede sig om, men krambodens varer var opregnet i skiftet, og her forekom masser af krydderier, kramvarer og tekstiler. ${ }^{56}$

At relationerne til Amsterdam var stærkere i Horsens end i Vejle, afspejles også i det forhold, at der var 68 immigranter fra Horsens, der giftede sig i Amsterdam i 1700-tallet, mod kun 10 fra Vejle. ${ }^{57}$ Den nyankomne handelsmand Toxen var således hverken den første eller den eneste i Horsens, der havde personlige erfaringer med Holland.

I de første år i Horsens blev Toxen ved med at tage til Amsterdam et par gange om året, men i november 1742 købte han en gård og indrettede en butik - en krambod - og fra da af fik han mindre tid til rejser. Allerede første sommer i den 
nye gård, skrev han, havde han så meget at gøre, at der ikke blev tid til at tage til Amsterdam. I 1744 blev han gift, og i de følgende år fik parret fem børn, hvoraf kun to piger overlevede.

\section{Hollandshandel fra Horsens}

Tilsyneladende kom Toxen efter sit giftermål i 1744 ikke til Amsterdam igen før i 1747, hvor hans søster var blevet forlovet med en Christopher Høbsman. ${ }^{58}$ De to kommende svogre fulgtes det år ad til Amsterdam, sandsynligvis for at Toxen kunne introducere ham til byens handelsliv. Høbsmann fik i 1752 farverbevilling i byen, ${ }^{59}$ og som forberedelsen til det har han haft god brug for at kende markedet i Amsterdam, hvorfra mange farvestoffer blev importeret. Året efter, da søsteren var blevet gift med Høbsmann, var de to svogre igen sammen i Amsterdam, men denne gang fulgtes de ikke ad derned, kun hjem.

De følgende år blev Toxen hjemme fra Amsterdam, men i 1751 lod han sig overtale af nogle købmænd og interessenter i byen til at tage med som købmand på et fartøj fra Horsens til Amsterdam med ærinder for flere forskellig erhvervsdrivende i byen. Fartøjet var en galease på 4-500 tønder, ${ }^{60}$ og skipperen havde ikke før været i Amsterdam ”og altså ukyndig i alle ting”. Desuden fik de en styrmand med fra Århus, som heller aldrig havde været i Amsterdam, skønt han påstod, at han havde. Man fornemmer, at Toxen var lidt utryg ved hele arrangementet, og han havde jo heller ikke selv før prøvet at sejle fra Horsens til Amsterdam. De kom dog derned på 14 dage og lå fire uger i byen. Hjemrejsen tog tre uger, hvor de måtte lægge ind flere steder undervejs. Toxen stod af et sted på den jyske østkyst og lejede en vogn til Århus og tog derfra videre til Horsens. ${ }^{61}$ I et særligt indhæftet blad i sine optegnelser gav Toxen en nærmere beskrivelse af denne rejse og særligt af den vanskelige indsejling til Amsterdam, men som tidligere nævnt er denne beskrivelse beklageligvis undladt af udgiveren.

Toxen omtaler ikke siden transporter fra Horsens direkte til Amsterdam, og hans handelsmæssige interesse har formentlig i stigende grad rettet sig mod skibstrafikken til Norge, som han eksporterede korn til. I foråret 1754 købte han en ottendepart i et fartøj fra byen, men det strandede allerede i oktober ved Fladstrand $^{62}$, et forlis, der kostede ham 300 rigsdaler i tabt skibspart, tabt last samt

\footnotetext{
58 Toxen skriver Christopher Høbskman.

591982 s. 175.

60 Antallet af tønder på en læst varierede efter typen af varer. Den danske skibslæst var principielt udtryk for skibenes lasteevne i ruglaster af 24 tønder, altså formodentlig et skib på 16-20 læster. Thestrup 1991, s. 24.

61 Toxen skriver, at han stod af ved Triemølle. Udgiveren C. Behrend foreslår, at det kan være Treaamølle, et udskibningssted nord for Grenaa.

62 Det nuværende Frederikshavn.
} 
bjærgeløn. Toxen nævner ikke selv yderligere skibsparter, men det fremgår af en liste over købmænd, der havde skibsparter i 1774, at han - i hvert fald i dette år - igen ejede en skibspart. ${ }^{63}$

Hjerting var altså tilsyneladende stadig den gængse vej for handlende i Horsens at få varer fra Holland. Af 1760'ernes toldregnskaber fra Varde ses, at fem til syv Horsens-borgere i hvert af årene 1761, 1763, 1767 og 1769 fik varer fra Holland ad denne vej. Varer, der gik den anden vej, var der derimod ikke mange af. I 1761 og 1763 eksporterede henholdsvis fem og seks borgere varer til Holland, i 1767 var der ingen fra Horsens, der udførte til Holland over Hjerting og i 1769 kun en. Horsens-folkenes eksportvarer var fåre- og lammeskind, beredte skind, pennefjer og voks.

Toxen - eller Töxen, som hans navn konsekvent skrives i toldregnskaberne - var blandt de købmænd, der både importerede og eksporterede. I 1761 sendte han en sending voks og pennefjer med skipper Jens Hansen af Hjerting og hans smakke på 711/2 læster den 7. juli. Tilbage fik han med samme skipper den 5. september en sending bestående af svesker, korender, mandler, nelliker, kardemomme, muskater, uldkarter, gråt papir, risengryn, rosiner og anis. I 1763 sendte han beredt skind med Søren Graversens smakke på 8 læster den 14. juni og fik anis, kaffebønner, mandler og uldkarter retur med samme skib den 26. juli. Samme skipper, Søren Graversen, strandede året efter ved Oksby nær Blåvands Huk på hjemrejsen fra Amsterdam, beretter Rasmus Toxen. Det meste af Toxens last gik tabt ved den lejlighed, og skønt 100 pund af den bedste indigo blev bjærget, "vel indpakket først i en Fustagie og siden i en Kiste", blev det efterfølgende "ranet og stiålen bort". ${ }^{64}$ I toldbogen hed det, at intet blev bjerget fra forliset. ${ }^{65}$

1767 eksporterede Toxen ingen varer til Holland, men fik med Jacob Boubjergs snekke på 11 læster den 6. august en sending varer. Det er den sidste af Toxens sendinger, vi kan følge i toldregnskaberne, og den bestod af 50 pund kaffebønner, et pund kanel, et halvt pund kardemomme, et halvt pund muskat, et halvt pund muskatblomme, 110 pund risengryn, 40 pund mandler og et dusin uldkarter - tilsammen lige godt 200 pund, eller 2/3 af vægten af den last, som Søren Rasmussen 36 år tidligere fik til Vejle. På den baggrund er det nok ikke forkert at konkludere, at hollandshandelen efterhånden ikke fyldte meget i den nu veletablerede Rasmus Toxens samlede virksomhed.

Med årene var Toxen nemlig blevet en af Horsens' store handelsmænd, der i 1750'erne årligt udførte 500-1000 tønder korn til Norge, og i 1760 oprettede han et maltgøreri, der producerede malt til udførsel. ${ }^{66}$ I 1774 fortælles det i en oversigt over byens handlende, at han handlede med "korn og fedevarer, tømmer

63 Bay 1982, s. 206.

64 Behrend 1906-08, s. 588.

65 Kristensen 1980, s. 554.

66 Bay 1982, s. 170 f. 
og fiel, stål, tiere, hør, hamp, fisk og specerie, men ei med fabriksvarer". ${ }^{67}$ Fabriksvarer, fremgår det af sammenhængen, var varer som silke, uldvarer, linned, galanterivarer, isenkram og silkebånd. Toxen var altså tilsyneladende gået bort fra at handle med silke, som ellers var den mest interessante vare for ham på den første Amsterdam-tur. Det fremgår heller ikke af toldlisterne, at han importerede tobak, men en episode i 1763 kan vække en lille mistanke om, at det måske alligevel hændte, at han havde fået lidt tobak med hjem uden for myndighedernes bevågenhed. Han beretter nemlig, at han dette år den 16. juni fik "inkvisition” af rådmand Flensburg og underbyfoged Brandt Farver, som sammen med fire betjente dukkede uanmeldt op og ransagede hans ejendom nøje for at lede efter hollandsk tobak. De fandt "Gud ske lov intet", skrev Toxen lettet, og skyndte sig at tilføje "thi jeg havde intet". Men mon ikke lettelsen alligevel skyldtes, at de godt kunne have fundet tobak på et mere uheldigt tidspunkt?

\section{At opbygge en købmandshandel}

Toxens optegnelser kan næsten læses som en strategisk manual til, hvordan man kunne opbygge en solid forretning i 1700-tallets østjyske købstæder ved at bruge de ressourcer man havde, arbejde aktivt med at styrke kundskaber, kapital, ejendomme og netværk og foretage de rigtige valg.

Selv om Rasmus Toxen blev faderløs som treårig og kun voksede op med sin mor, var han på ingen måde uden familiemæssig baggrund og netværk. Hans far var præstesøn fra Løsning, og hans mor var søn af borgmesteren i Kolding. Livet igennem gjorde Toxen brug af sin familie til at hjælpe og til at knytte kontakter. Han fik en læreplads hos manden til sin fars søsterdatter på Fyn, han besøgte et søskendebarn i Hamburg, han fik først sin moster og siden sin søster til at holde hus for sig, da han som ungkarl etablerede sig i Horsens. Hans kone kom fra et nærliggende stort gods, han fik en anden søster til byen og gift med en handlende i byen, og da hans to døtre blev voksne, blev de gift med henholdsvis en købmand og en apoteker i byen. Alle disse relationer kan anskues som en form for strategiske alliancer, der bidrog til at styrke hans netværk og udviklingen af hans virksomhed. Tilsyneladende var Toxen meget bevidst om, at netværk er personlige og skal vedligeholdes, også selv man ikke i øjeblikket gør brug af dem. Således opretholdt han kontakt med venner i Hamburg, skønt hans forretningsmæssige hovedinteresse rettede sig mod Holland og Norge, og han derfor ikke brugte byen i nogen videre udstrækning. Ligeledes videregav han hjælp, på samme måde som han selv var blevet hjulpet. Ligesom han selv i sin tid blev introduceret til Amsterdam af skipperen på skibet, sørgede han for at introducere andre til byen. 
I første omgang gjaldt det hans svoger Høbsmann, som han var sammen med i Amsterdam to år i træk, og i anden omgang tog han med et Horsens-skib til Amsterdam for som stedkendt at hjælpe de lokale Horsens-købmænd med at gøre forretninger der.

Mobilitet og kendskab til fremmede forhold synes at have været et af nøgleordene i hans strategi. Det ser ud til, at han ret systematisk opsøgte steder, hvor han kunne erhverve et kendskab til markedet, der kunne hjælpe ham i opbygningen af hans virksomhed. Da han efter sin mislykkede læreplads påbegyndte sin rejseaktivitet, tog han først en tur rundt om de større byer i nærområdet, København, Eckernförde og Kiel, for derefter at lande i Hamburg, hvor han tilbragte flere måneder. På sin næste rejse tilbragte han fire ugers i Holland, hvor han ikke nøjedes med at besøge handelscentret Amsterdam, men også foretog en rejse gennem andre hollandske byer. Han havde dermed i løbet af godt et år ikke alene haft længere ophold i to af datidens økonomisk mest betydningsfulde byer i Nordeuropa, Hamburg og Amsterdam, han havde også orienteret sig mere bredt i området, inden han lagde sig fast på Amsterdam som sit foretrukne rejsemål.

Rejserne til Holland tog en stor del af hans tid i de første år af hans karriere, hvor han drev handel med udgangspunkt i den lille købstad Vejle. Efter nogle år flyttede han til en større købstad for at etablere sig, men havde endnu et par år med Amsterdam-handelen som basis. Først da han begyndte at investere i fast ejendom, aftog hans personlige deltagelse i rejserne til Holland. Opmærksomheden blev i stedet rettet mere mod handelen på Norge. Som 57-årig købte han i 1773 en bondegård i den nærliggende landsby Nim og begyndte dermed at forberede sin tilbagetrækning fra købmandskabet. Gennem de følgende år opbyggede han ved tilkøb en større besiddelse i landsbyen, hvortil han flyttede i 1780 og tilbragte sine sidste år som jordbruger. Trods en vis mobilitet livet igennem var Toxen stedbunden, når det gjaldt hans boliger - de alle lå inden for en radius af $20 \mathrm{~km}$.

Samlet set havde Toxen en sammensat økonomi med en stor risikospredning, og han justerede livet igennem vægtningen af sine forretninger. I begyndelsen af sin handelsvirksomhed i Vejle fokuserede han først og fremmest på lette varer og kapital. Senere, da han etablerede sig i Horsens, investerede han i fast ejendom, og hans forretningsmæssige fokus blev her korn og andre grovvarer, som stillede visse krav til faste anlæg. Med tiden investerede han også i produktion og transport i form af maltgøreri og en skibspart, og endelig fulgte investering i landejendom med henblik på sikring af alderdommen. 


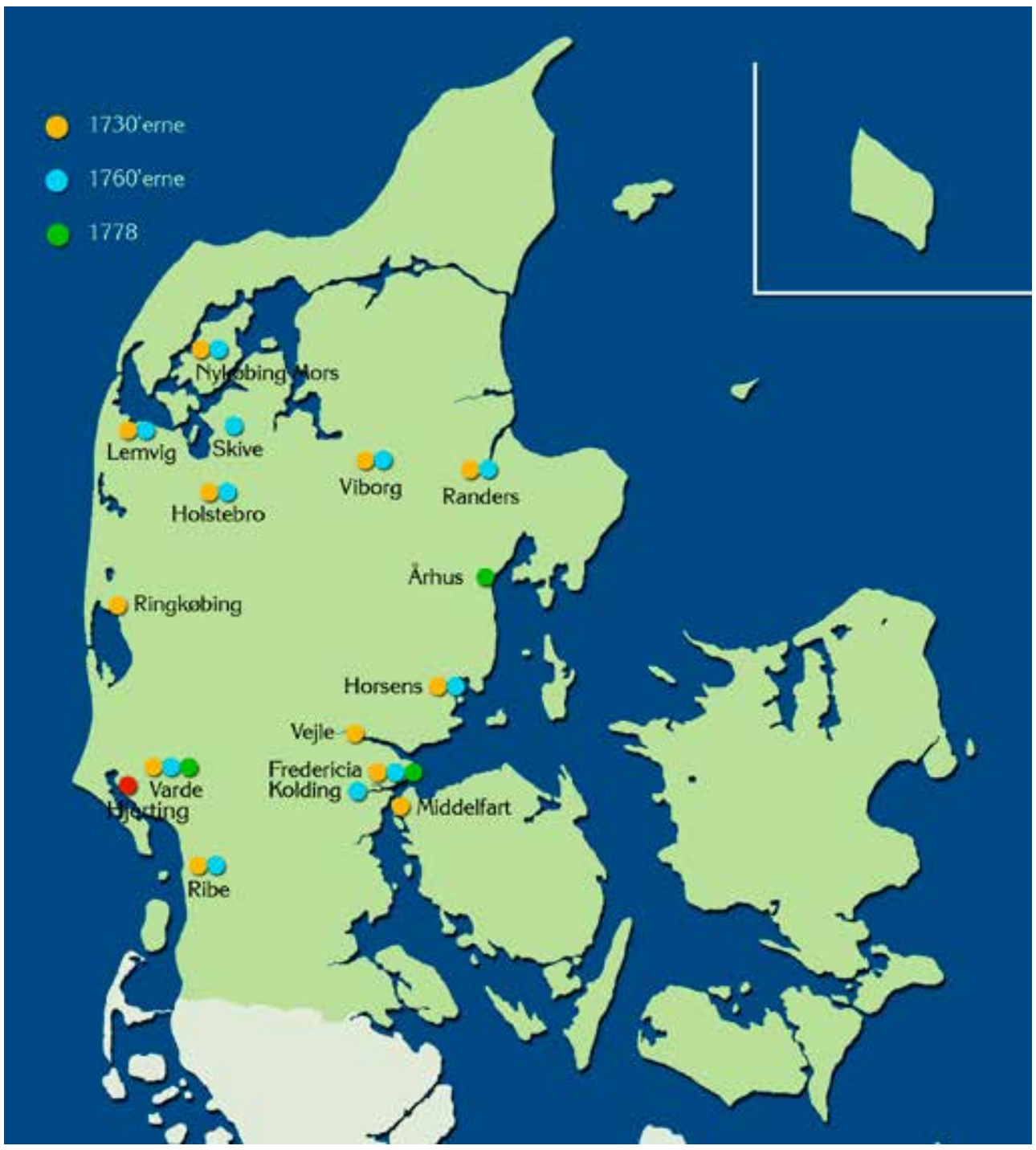

Købstæder, der importerede varer fra Holland over Hjerting i 1700-tallet. I alt 14 jyske købstæder mellem Limfjorden og Kongeåen fik varer fra Holland over Hjerting. Varde Toldbøger, diverse årgange. Grafik: Niels Knudsen.

\section{Hjerting som transithavn for hele Jylland}

Rasmus Toxen var blot en af de mange, der drog nytte af Hjertings livlige kontakt med Holland og hentede varer fra direkte fra Amsterdam til Jylland. Importørerne af varer fra Holland var først og fremmest borgere i de kongerigske købstæder i Jylland. Formentlig var de primært handlende, men der var også visse erhvervsgrupper - som f.eks. farvere, apotekere, garvere - der havde særligt behov for de materialer, der kunne skaffes fra Holland. I alt 14 jyske købstæder mellem Kongeåen og Limfjorden - med Nykøbing Mors som den nordligste - fik på et eller andet tidspunkt i de syv repræsenterede år leveret varer fra Holland over Varde 
toldsted. Desuden fik Middelfart på Fyn en enkelt gang leveret varer, hvorimod ingen byer nord for Limfjorden eller syd for Kongeåen fik varer fra Holland ad denne vej. Hertil kommer, at der næsten hvert år var mellem en og fem personer uden for købstæderne, der fik leveret varer, ligesom en skipper en sjælden gang imellem - i hvert fald efter hvad han opgav til toldvæsenet - havde noget med for sig selv. De købstæder, hvor antallet af importører sammenlagt gennem perioden var størst, var Holstebro, Varde, Viborg og Horsens, og det er også disse købstæder, der er repræsenteret de første seks bevarede todlbøger. I 1798, hvorfra den næste bevarede toldbog stammer, var det stort set kun var Vardekøbmænd, der fik varer fra Holland over Hjerting. Dette forhold afspejler den udvikling, der var sket igennem 1700-tallet, hvor handelsaktiviteten mellem Holland og Danmark dels var dalende, dels i stigende grad blev koncentreret i København. Mens flere provinsbyer tidligere havde haft direkte kontakt med Holland, var det i perioden 1719-1755 kun Aalborg og den jyske vestkyst, der endnu havde direkte kontakt med Holland. ${ }^{68}$ Hamburg og Altona overtog gennem 1700-tallet i stigende grad rollen som leverandør af luksus- og kolonialvarer, der blev importeret over Hjerting. ${ }^{69}$ I Holland mærkede man i stigende grad konkurrencen fra såvel London og Hamburg, og med den franske invasion af den Hollandske Republik i 1795 og opløsningen af VOC få år senere var Hollands rolle som en førende aktør i verdenshandelen forbi.

\section{Ny vinkel på toldregnskaberne}

Toxens optegnelser fra sit liv som købmand i to købstæder på den jyske østkyst giver et værdifuldt supplement til de oplysninger, man kan udlede af 1700-tallets toldregnskaber, og de giver et mere detaljeret indblik i, hvordan handelen er foregået. I det følgende skal vi se nærmere på nogle af de områder, hvor Toxens optegnelser særligt bidrager med oplysninger, der ikke fremgår af toldregnskaberne.

Det omtales ikke i toldregnskaberne, at der var købmænd, der fulgte med varerne. At dømme efter Toxens optegnelser var det imidlertid ikke ualmindeligt, at købmanden selv var med på rejsen til Amsterdam, så han kunne tage vare på sine penge eller varer og selv udsøge sig sine varer i Amsterdam. Toldregnskaberne registrerede kun den persontransport, som skete uden medfølgende varer, hvilket i ganske få tilfælde vil sige regulære passagerer. Den oftest forekommende passagertrafik var transporten af de søfolk, der om foråret skulle til Holland for at søge hyre. Toldregnskaberne fra Varde ville i disse tilfælde oftest oplyse, at der var ”en del søfarende folk” med skibet. Hos Toxen kan vi så høre, at "en del” faktisk

68 Kelsall 2007, s. 137.

69 Denne udvikling er detaljeret gennemgået i Guldberg 2013. 


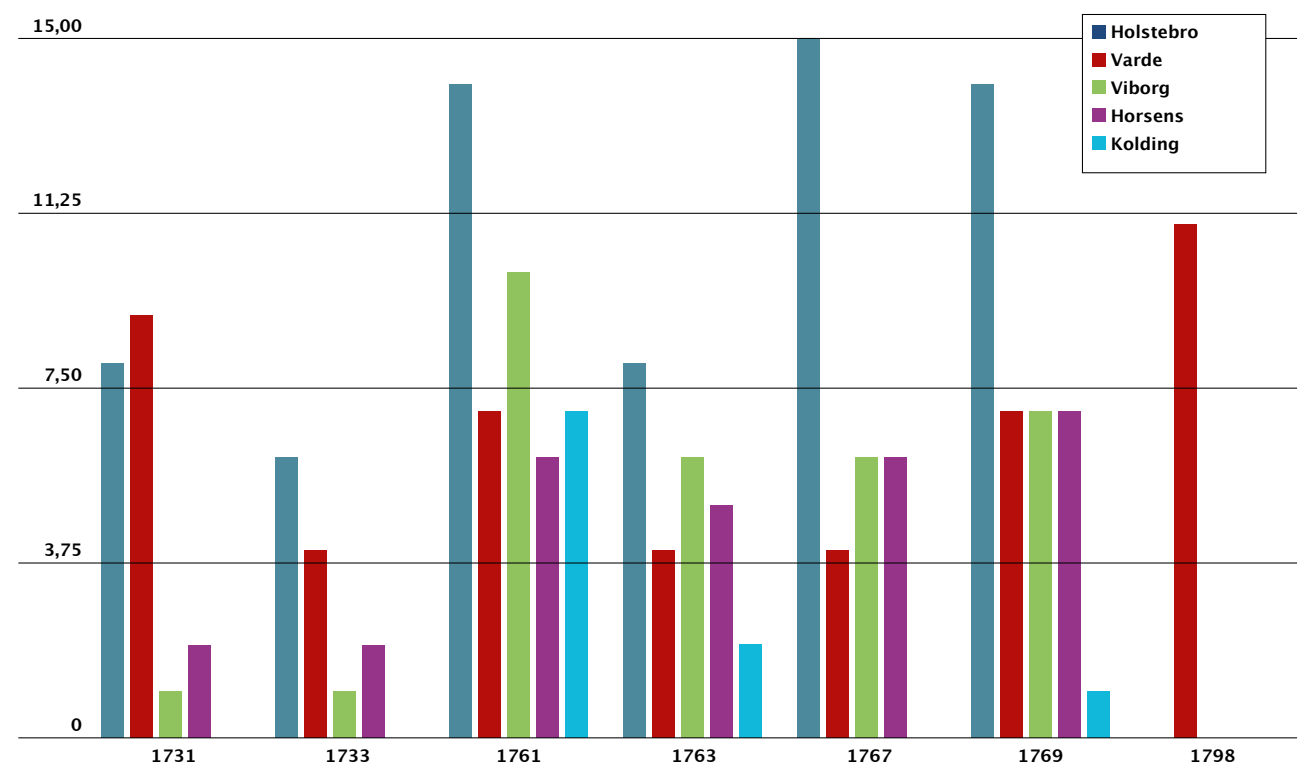

Antal personer, der importerede varer fra Holland over Hjerting i 1700-tallet, i de fem jyske byer med det største antal importører. Varde Toldbøger, diverse årgange

kunne dække over et antal på mere 50 matroser, hvilket bidrager til indtrykket af, at arbejdskraft var blandt de mere betydningsfulde eksportartikler fra Jylland til Amsterdam. Desuden giver det en fornemmelse af den trængsel, der kunne være om bord på de forholdsvis små skibe, hvis besætning ellers typisk kun ville omfatte en skipper, en matros og måske en dreng. ${ }^{70}$

Toxen angiver også nogle ret præcise sejltider, som illustrerer, at transporttiden mellem Hjerting og Holland kunne variere med adskillige uger. Man kunne blive blæst derned på fire dage, som det skete for ham på rejsen i 1738, eller man kunne slås med vind og vejr og lække fartøjer i ugevis som på rejsen i 1739. Ligeledes bidrager Toxen med oplevelser af skibstrafikkens usikkerhed med beskrivelser af strandinger, forlis og bjærgning. Hvordan det kunne være med til at redde en kritisk situation, at der var mange matroser om bord, hvordan et forlis kunne fratage købmanden, der havde part i skibet, en mindre formue på ganske kort tid, og hvordan varer, der egentlig var blevet bjærget, kunne forsvinde igen.

Toxen kaster også nyt lys over skipperens rolle. Skipperen var ikke bare en person, der sørgede for at få bragt skibet fra den ene lokalitet til den anden, han kunne også have en formidlende rolle, når det gjaldt om at hjælpe nye, unge handlende i gang, ved at skaffe dem de rette kontakter i storbyen. Knud Risbøl synes at have været særligt specialiseret på Holland og de mange varetyper der-

70 Oplysninger for besætningsstørrelsen findes kun i Varde toldbog 1798, hvor skibe af den størrelse, Toxen sejlede med, var bemandet med skipper, matros og dreng. På en skibsliste fra Tønder Toldsted 1777 bestod besætningen på et tilsvarende skib i flere tilfælde kun af skipper og matros. Varde Toldbog 1798; Tønder Told 1777. 
fra. Desuden kan Toxens oplevelse i 1739, hvor han først i Hjerting og siden i Amsterdam kom for sent til at komme med Hjerting-skibe, tyde på, at skipperne gerne fulgtes ad på turen til og fra Amsterdam. Det er dog ikke et mønster, der tydeligt lader sig bekræfte af toldregnskaberne.

Endelig er det interessant at få slået fast, at Hjerting-skibene rent faktisk anløb selve Amsterdam. I toldregnskaberne angives deres destination kun som "Holland”, og det kan derfor ikke ud af dem læses, om fartøjerne kom helt ind til byen, eller de anvendte en form for ladeplads i en vis afstand. Toxens optegnelser levner næppe nogen tvivl om, at skibene kom helt ind til Amsterdam.

Et forhold, der ikke findes information om i Toxens optegnelser, er hvordan man klarede sig rent sprogligt. Hvilket sprog anvendte han i Holland, og var det let eller svært at kommunikere? Kunne man tænke sig, at den kommissær, han kom i kontakt med, også var sprogkyndig og således i stand til at tale med nytilkomne købmænd? Eller var sproget bare ikke noget problem og blev derfor ikke nævnt? Interessant er det i øvrigt i denne sammenhæng at konstatere, at Toxen ikke med et ord nævner sin eventuelle skolegang, og hvad den måtte have bibragt ham af sprogkundskaber eller andet, der kunne komme ham til nytte i hans senere karriere. Toxen synes at have været en udpræget handlingens mand, som snarere fokuserede på at tilegne sig viden ved praktisk købmandskab end ved boglige studier.

Toxens beretning fortæller historien om en købmand, der udviklede sin virksomhed i samspil med en af verdenshandelens metropoler, og som var med til at bringe dens varer ud til borgere i de jyske købstæder. Bønder på besøg i købstaden kunne også købe krydderier og de andre varer fra fjerne egne hos købmanden, og på den måde fik Jylland en flig af de mange varer, den nye globaliserede økonomi bragte på markedet. ${ }^{71}$

Toxen personificerer på sin vis Jyllands samhandel med Holland. I flere generationer stod Holland stærkt i de jyske købmænds bevidsthed, og stadig i 1730'erne var det et interessant marked for en nybegynder i handelsfaget. I løbet af 1700-tallet overtog Hamburg imidlertid mange af de funktioner, Amsterdam tidligere havde haft. Mens varestrømmen fra Amsterdam vedblev at have omtrent samme sammensætning i 1760'erne, som den havde haft i 1730'erne, strømmede det ind med moderne luksusvarer og spændende nyheder fra Hamburg. ${ }^{72}$ På det tidspunkt var Toxens forretningsmæssige aktiviteter dog i stedet rettet sig mod Norge. Når vi kigger på Toxens sidste kendte leverance fra Holland i 1767, bestående af kaffebønner, krydderier, risengryn, mandler og uldkarter pakket i tre små tønder og en kasse, er det nærliggende at se det som symbolet på, at Holland

71 I doktordisputatsen Luksus fra 2013 behandler Mikkel Venborg Pedersen indgående, hvordan 1700-tallets voksende varestrøm fra de oversøiske kolonier gav sig udslag i en markant ændring af forbrugsmønstre og forfinelse af vaner i fem danske hjem, og hvordan de - ligesom europæerne i det hele taget - stille og roligt fik mere af verden ind i dagligstuen. Venborg Pedersen 2013.

72 Guldberg 2013. 
lige så stille forsvandt ud af interessesfæren selv hos en ivrig Hollands-farer fra Horsens.

\section{Litteratur}

Bay, Svend Aage 1982: Horsens historie indtil 1837. Horsens Kommune.

Becker-Christensen, Henrik 1988: Protektionisme og reformer 1660-1814. Dansk Toldhistorie II, Toldhistorisk Selskab.

Berend, C. 1906-08: ”En Horsenskøbmands Optegnelser fra det 18de Aarhundrede”. Samlinger til Jydsk Historie og Topografi, 3. række V. Bind. København 1906-08, s. 575-597.

Bochove, Christiaan van 2008: The Economic Consequences of the Dutch. Ecoomic integration around the North Sea, 1500-1800. Aksant, Amsterdam.

Christensen, Asger Nørlund 2014: "Flådens udlandsmobilisering: Rekruttering af skandinaviske søfolk i Amsterdam under Skånske krig”. Fra krig og fred. Dansk Militærhistorisk Kommissions Tidsskrift 2014/1, s. 11-59.

Christensen, C. Petresch 1921: „Vejle Købstad og dens indbyggere ved Aar 1735“. Vejle Amts Aarbøger, s.174-204.

Damgaard, Ellen, Mette Guldberg \& Poul Holm (eds.) 1998: A North Sea Region. West Jutland and the World II. Esbjerg.

Fabricius, Knud, L.L. Hammerich og Vilh. Lorenzen (red.)1945: Holland Danmark. Bd. I-II. København.

Feldbæk, Ole 1990: Gyldendal og Politikens Danmarkshistorie bd. 9 Den lange fred 1700-1800. Gyldendal og Politiken.

Gawronski, Gerzy (ed.) 2012: Amsterdam ceramics. A city’s history and an archaeological ceramics catalogue 1175-2011. Uitgeverij Bas Lubberhuizen, Bureau Monumenten \& Archeologie.

Gijsbers, Wilma 1999: Kapitale Ossen. De internationale handel in Slachtvee in Noordwest-Europa (1300-1750) Uitgeverij Verloren, Hilversum.

Graugaard, Esben 1996: ”Den nederlandske forbindelse. Kontakter mellem Holstebro - en by i den vestjyske periferi - og Amsterdam - verdenshandelens metropol - ca. 1600-1800”. FRAM 1996, s. 17-28.

Guldberg, Mette 1997: ”Hollandsfarere - Risbøl'erne i Hjerting”. Sjæk’len 1996. Årbog for Fiskeri- og Søfartsmuseet, Saltvandsakvariet i Esbjerg. Esbjerg, s. 9-17.

Guldberg, Mette 1998: ”Skibsfarten på Ribe i 1730`erne”. Sjæk’len 1997. Årbog for Fiskeri- og Søfartsmuseet, Saltvandsakvariet i Esbjerg. Esbjerg s.16-27.

Guldberg, Mette 1999: Jydepotter fra Varde-egnen. Produktion og handel ca.1650-1850. Landbohistorisk Selskab. 
Guldberg, Mette 2013:”De varer, som bonden aldrig ser? Importen over Hjerting fra Holland i 1700-tallet”. Sjæklen 2012, Årbog for Fiskeri- og Søfartsmuseet, Saltvandsakvariet i Esbjerg. Esbjerg, s. 66-81.

Guldberg, Mette 2014: ”Fartøjer i det nordlige Vadehav”. Sjæklen 2013. Årbog for Fiskeri- og Søfartsmuseet, Esbjerg s. 29-39.

Guldberg, Mette, Poul Holm \& Per Kristian Madsen (eds.) 1993: Facing the North Sea. West Jutland and the World. Esbjerg.

Gøbel, Erik 2008: Øresundstoldregnskaberne - et internationalt skatkammer. Siden Saxo 2008-2, 16-24.

Heeres, W.G., L.M.J.B. Hesp, L. Noordegraaf \& R.C.W van der Voort (eds.) 1988: From Dunkirk to Danzig; shipping and trade in the North Sea and the Baltic, 1350-1850. Essays in honour of J.A. Faber on the occasion of his retirement as professor of the Economic and Social History at the University of Amsterdam. Netherlands Economisch-Historisk Archief, Amsterdam.

Hoff, Annette 2007: Gehrdt de Lichtenberg. Storkøbmand, godsejer, pengeudlåner og fabrikant. Horsens Museum, Dansk Center for Herregårdsforskning. Jacobs, Els M. 1991: In Pursuit of Pepper and Tea. The Story of the Dutch East India Company. National Maritime Museum Amsterdam, Walburg Pers.

Jensen, J.K. 1944: Blade af Horsens Købstads Historie. Horsens.

Kelsall, Phillip 2004: Crisis and Change. The Development of Dutch-Danish Maritime Trade 1639-1755. Ph.d.-afhandling, Århus Universitet, 2007 (upubliceret).

Kristensen, H.K. 1974, 1976 og 1977: ”Skibsfart fra Ribe-Varde-Blåvandshukområdet i gammel tid”. Fra Ribe Amt XVII-3, 1974, 363-403, XX-I, 1976, 69134, XX-2, 1977, 386-455.

Kristensen, H.K. 1980: ”Strandinger 1763-85 på kysten af Varde-Hjerting tolddistrikt”. Fra Ribe Amt 1908, s. 553-557.

Kromann, N.M. 1933: Fanøs Historie I, Esbjerg.

Lange, Nikolai Bendix 1793: Statistische Briefe über Dännemark, Norwegen, Schleswig und Holstein. Altona.

Lottum, Jelle van 2007: Across the North Sea. Labour migration in the North Sea region c. 1550-1850. Aksant Amsterdam.

Mortensen, Per Hauge 1989: ”Om toldregnskabers troværdighed”. Nogle eksempler fra perioden 1750-1800. FRAM 1989, s. 77-89

Mortensen, Per Hauge 1991: ”Sejlads på Ringkøbing. Fra accise- og toldregnskaber 1680-1798". FRAM , s. 34-42.

Møller, Anders Monrad 1975: ”Kongerigske toldregnskaber fra det 18. århundrede”. Fortid og Nutid Bind XXVI, s. 86-103.

Møller, Anders Monrad 1981: Fra galeoth til galease. Studier i de kongerigske provinsers søfart i det 18. århundrede. Esbjerg. 
Nyborg, Ebbe et al. (red.)1988-91: Danmarks kirker. Ribe Amt XIX: III bind. Nationalmuseet. Herning.

Pedersen, Max 2013: "Fra Vadehavet til Amsterdam”. Sjæk’len 2012. Årbog for Fiskeri- og Søfartsmuseet, Saltvandsakvariet i Esbjerg. Esbjerg 2013, s. 83-103.

Pedersen, Max og Frans Thuijs 2014: "Fra Vadehavet til skafottet i Amsterdam om kriminaliteten blandt vadehavsmigranterne i 1600- og 1700-tallets Holland”. Sjæk’len 2013. Årbog for Fiskeri- og Søfartsmuseet, Saltvandsakvariet i Esbjerg. Esbjerg, s. 9-27.

Pontoppidan, Erich 1768: Den Danske Atlas eller Konge-Riget Dannemark, Tomus IV, København.

Poulsen, Bo 2008: Dutch Herring. An environmental History c. 1600-1860. Aksant Amsterdam.

Rohden Olesen, Claus: Den nederlandske indflydelse på det skandinaviske skibsbyggeri i De Forenede Nederlandes storhedstid. I: Maritim Kontakt 35. Nederlandsk i Norden. Den nederlandske teknologis indflydelse på renæssancens martitime Skandinavien. København 2012. P. 69-252.

Sogner, Sølvi 1994: Ung i Europa. Norsk ungdom over Nordsjøen til Nederland i tidlig nytid. Universitetsforlaget Oslo.

Sogner, Sølvi 2012: ”Og skuta lå i Amsterdam...” Et glemt norsk innvandrersamfunn i Amsterdam 1621-1720. Aschehoug \& co, Oslo.

Sundbo, A. 1915-18 og 1919-22: "Af Varde og Hjertings Historie”. Fra Ribe Amt IV, s. 524-563, s. 573-606 og Fra Ribe Amt V, s. 65-107.

Thestrup, Poul 1991: Pund og alen. Danske mål- og vægtenheder fra 1683-reformen til i dag. Arkivernes informationsserie. Rigsarkivet/GAD.

Thaarup, Thorbjørn: Først af de Nederlender... Det nederlandske aftryk på søkort, fyrvæsen og lovgivning i renæssancens Danmark. I: Maritim Kontakt 35. Nederlandsk i Norden. Den nederlandske teknologis indflydelse på renæssancens maritime Skandinavien. København 2012, 8-68.

Venborg Pedersen, Mikkel, 2013: Luksus. Forbrug og kolonier i Danmark i det 18. århundrede. Museum Tusculanums forlag, Københavns Universitet.

\section{Utrykte kilder}

Varde Toldbøger 1731, 1733, 1761, 1763, 1767, 1769 og 1798. Rigsarkivet, Rentekammeret og Generaltoldkammeret. Reviderede Regnskaber. Vardes Regnskaber for Told og Konsumtion m.v. Pakke 6-11, 14 og 15.

Tønder Told 1777. Rigsarkivet 571 Reviderede regnskaber Slesvig-Holstenske toldregnskaber 1684-1863, Tønder m.m. Kasse 4 1777-1794. 


\section{English Summary}

The article deals with imports of goods from Holland to the Jutland market towns in the 1700s, and the traders and captains who were active in this trade. In the 1600s and 1700s Holland was a northern European centre for the trade in goods from the overseas colonies. While many Danish towns received goods from Holland via Copenhagen, a number of Jutland merchants got their goods directly from Holland via the harbours on the southwestern coast of Jutland. The customs records from the 1700s are a good source for this trade, but other questions are left open. In this respect one can find help in some of the rare personal accounts that exist from the era. One of these is the records of the East Jutland merchant Rasmus Toxen, which are taken as a starting point in this article for a portrayal of the contacts between the Jutland province and one of the centres of world trade.

Rasmus Toxen (1716-1786) functioned as a merchant in Vejle at the end of the 1730s and in Horsens from 1740 until his retirement in 1785. At the beginning of his career he himself went several times to Amsterdam to fetch goods for his business. The most important harbour for this traffic in the 1700s was the market town of Varde's port, Hjerting, from which several ships sailed in the Holland trade. In the customs records one can find information about the ships, the names and home bases of the captains, their destination, their cargoes and the owners of the goods. Rasmus Toxen's records supplement this with information on conditions on board, on passenger transport, on sailing schedules, on destinations in Holland and on the dangers to shipping. Alongside this Rasmus Toxen's notes provide a picture of a merchant who throughout his life built up a business by making use of his resources and working actively to strengthen his knowledge, capital and network. Viewed as a whole the material reflects Holland's declining importance as a centre of trade through the 1700 s. 